Uniwersytet im. Adama Mickiewicza, Poznań

\title{
Dostęp do informacji publicznej a ochrona prywatności osób, które przestały pełnić funkcję publiczną
}

Ostęp do informacji traktowany jest obecnie w społeczeństwie obygwarancje prawne zostały sformułowane na poziomie międzynarodowym, europejskim, jak i krajowym. Jeżeli chodzi o tę pierwszą płaszczyznę, to przywołać należy chociażby art. 19 Powszechnej Deklaracji Praw Człowieka ${ }^{2}$, i art. 19 ust. 2 Międzynarodowy Pakt Praw Obywatelskich i Politycznych z 19 grudnia $1966 \mathrm{r}^{3}$ Na płaszczyźnie europejskiej prawo dostępu do informacji gwarantowane jest w Europejskiej Konwencji

1 P. Szustakiewicz, Dostęp do informacji na podstawie ustawy o dostepie do informacji publicznej, w: Obywatelskie prawo do informacji, red. T. Gardocka, Warszawa 2008, s. 13.

2 Powszechna Deklaracja Praw Człowieka z 10.12.1948 r. Tekst dostępny na stronie internetowej http://www.unesco.pl/fileadmin/user_upload/pdf/Powszechna_Deklaracja_Praw_Czlowieka.pdf. Zgodnie z art. 19 tego aktu „Każdy człowiek ma prawo wolności opinii i wyrażania jej; prawo to obejmuje swobodę posiadania niezależnej opinii, poszukiwania, otrzymywania $\boldsymbol{i}$ rozpowszechniania informacji i poglądów wszelkimi środkami, bez względu na granice".

Dz. U. 1977, Nr 38, poz. 167. Zgodnie z ust. 2 tego przepisu „Każdy człowiek ma prawo do swobodnego wyrażania opinii; prawo to obejmuje swobodę poszukiwania, otrzymywania $\boldsymbol{i}$ rozpowszechniania wszelkich informacji i poglądów, bez względu na granice państwowe, ustnie, pismem lub drukiem, w postaci dzieła sztuki bądź w jakikolwiek inny sposób według własnego wyboru”. W ust. 3 art. 19 przewidziano pewne możliwości wprowadzenia ograniczeń w tej sferze. Zgodnie z tym przepisem „Realizacja praw przewidzianych w ustępie 2 niniejszego artykułu pociaga za sobą specjalne obowiązki i specjalną odpowiedzialność. Może ona w konsekwencji podlegać pewnym ograniczeniom, które powinny być jednak wyraźnie przewidziane przez ustawę i które są niezbędne w celu: a) poszanowania praw i dobrego imienia innych; b) ochrony bezpieczeństwa państwowego lub porządku publicznego albo zdrowia lub moralności publicznej. 
o Ochronie Praw Człowieka z 4 listopada 1950 r. ${ }^{4} \mathrm{~W}$ prawie Unii Europejskiej kwestia ta została poruszona w art. 6 ust. 2 Traktatu o Unii Europejskiej $^{5}$ poprzez odwołanie do postanowień Europejskiej konwencji o ochronie praw człowieka i podstawowych wolności ${ }^{6}$, a nadto w art. 15 Traktatu o funkcjonowaniu Unii Europejskiej ${ }^{7}$. Gwarancje dostępu do informacji zapisano także w art. 11 ust. 1 Karty Praw Podstawowych Unii Europejskiej ${ }^{8}$. Kwestie szczegółowe dotyczące dostępu do dokumentów organów Unii uregulowano w rozporządzeniu nr 1049/2001 Parlamentu Europejskiego i Rady z dnia 30 maja 2001 r. w sprawie publicznego dostępu do dokumentów Parlamentu Europejskiego, Rady i Komisji ${ }^{9}$ oraz dyrektywie Parlamentu Europejskiego i Rady nr 2003/98/WE z 17 listopada 2003 r. w sprawie ponownego wykorzystywania informacji sektora publicznego ${ }^{10}$.

Przypomnieć także trzeba, że prawo dostępu do informacji publicznej jest normą konstytucyjną. Zgodnie z art. $61^{11}$ Konstytucji Rzeczypospoli-

4 Dz. U. 199, Nr 61, poz. 264 z późn. zm. Zgodnie z art. 10 Konwencji „1. Każdy ma prawo do wolności wyrażania opinii. Prawo to obejmuje wolność posiadania poglądów oraz otrzymywania i przekazywania informacji i idei bez ingerencji władz publicznych i bez względu na granice państwowe. Niniejszy przepis nie wyklucza prawa Państw do poddania procedurze zezwoleń przedsiębiorstw radiowych, telewizyjnych lub kinematograficznych. 2. Korzystanie z tych wolności pociagających za sobą obowiązki i odpowiedzialność może podlegać takim wymogom formalnym, warunkom, ograniczeniom i sankcjom, jakie są przewidziane przez ustawę i niezbędne w społeczeństwie demokratycznym w interesie bezpieczeństwa państwowego, integralności terytorialnej lub bezpieczeństwa publicznego ze względu na konieczność zapobieżenia zakłóceniu porządku lub przestępstwu, z uwagi na ochronę zdrowia i moralności, ochronę dobrego imienia i praw innych osób oraz ze względu na zapobieżenie ujawnieniu informacji poufnych lub na zagwarantowanie powagi i bezstronności władzy sądowej”.

5 Wersja skonsolidowana Traktatu o Unii Europejskiej, Dz. U. U.E. 30.03.2010, C 83, s. 13-45.

6 M. Bąkiewicz, Prawo do informacji w jednostkach samorzqdu terytorialnego, w: T. Gardocka (red.), op. cit., s. 13.

7 Dawny art. 255 TWE. Wersja skonsolidowana Traktatu o funkcjonowaniu Unii Europejskiej, Dz. U. U.E. 30.03.2010, C 83, s. 47-403.

8 Dz. U. U.E. 30.03.2010, C 83, s. 389-403. Zgodnie z tym przepisem „Każdy ma prawo do wolności wypowiedzi. Prawo to obejmuje wolność posiadania poglądów oraz otrzymywania i przekazywania informacji i idei bez ingerencji władz publicznych i bez względu na granice państwowe".

9 Dz. U. U.E. L 145, poz. 43. Patrz szerzej P. Szustakiewicz, op. cit., s. 14-15.

10 Dz. U. U.E. 31.12.2003, L 345, s. 90-96.

11 W doktrynie podkreśla się, iż uprawnienia gwarantowane art. 61 nie mogą być utożsamiane z gwarancjami przyznanymi na mocy art. 54 Konstytucji, przyzna- 
tej Polskiej ${ }^{12}$ obywatel ma prawo do uzyskiwania informacji o działalności organów władzy publicznej oraz osób pełniących funkcje publiczne ${ }^{13}$. Obejmuje ono uzyskiwanie informacji o działalności organów administracji rządowej i samorządowej, ale także - co należy szczególnie podkreślić - innych osób oraz jednostek organizacyjnych w zakresie, w jakim wykonują one zadania władzy publicznej i gospodarują mieniem komunalnym lub majątkiem Skarbu Państwa. Zatem każdy podmiot, który wykonuje powierzone zadania publiczne i dysponuje informacją publiczną ma obowiązek udostępnić taką informację ${ }^{14}$. W ten sposób, próbuje się zapewnić przejrzystość życia publicznego i możliwość realnej kontroli społecznej tej sfery. Podkreśla się jednocześnie, że „informacja o działalności osób pełniących funkcje publiczne jest informacją publiczną tylko w tym zakresie, w jakim wiąże się z pełnionymi przez te osoby funkcjami publicznymi, tj. działalnością publiczną. Związek ten musi być wyraźny i rzeczywisty, ale nie musi być bezpośredni. W zakresie przedmiotowym tego prawa mogą więc znaleźć się informacje dotyczące sfery życia osób pełniących funkcje publiczne, które objęte są konstytucyjnymi gwaran-

jącemu m.in. wolność pozyskiwania informacji. Patrz szerzej J. Sobczak, Prawo prasowe. Komentarz, Warszawa 2008, s. 195-196.

12 Konstytucja Rzeczypospolitej Polskiej z dnia 2 kwietnia 1997 r., Dz. U. Nr 78, poz. 483 z późn. zm. Patrz szerzej B. Banaszak, Konstytucja Rzeczypospolitej Polskiej. Komentarz, Warszawa 2009, s. 306-319. Zob. także Konstytucja III RP w tezach orzeczniczych Trybunatu Konstytucyjnego $i$ wybranych sqdów, Warszawa 2008, s. 302-311; K.Tarnacka, Prawo do informacji w polskim prawie konstytucyjnym, red. M. Zubik Warszawa 2009, s. 137 i n.

${ }_{13}$ P. Winczorek, Komentarz do Konstytucji Rzeczypospolitej Polskiej z dnia 2 kwietnia 1997 r., Warszawa 2000, s. 83. W kwestii wątpliwości co do pojęcia osoby pełniącej funkcję publiczną patrz szerzej B. Banaszak, op. cit., s. 311-315. Autor przywołuje definicję tego pojęcia sformułowaną przez TK (wyrok z 20.3.2006 r. K 17/05, OTK - A2006, Nr 3, poz. 30), a mianowicie iż są to „osoby, które związane są formalnymi więzami z instytucją publiczną, [...] chodzi o takie stanowiska i funkcje których sprawowanie jest równoznaczne z podejmowaniem działań wpływających bezpośrednio na sytuację prawną innych osób lub łączy się co najmniej z przygotowaniem decyzji dotyczących innych podmiotów. Spod zakresu funkcji publicznej wykluczone są zatem takie stanowiska, choćby pełnione w ramach organów władzy publicznej, które mają charakter usługowy lub techniczny". Ibidem, s. 312. Autor zauważa jednak, że w orzecznictwie sądowym ugruntował się pogląd, aby zakres tego pojęcia obejmował szerszy krąg podmiotów.

${ }_{14}$ T. R. Aleksandrowicz, Komentarz do ustawy o dostęie do informacji publicznej, Warszawa 2002, s. 91; P. Szustakiewicz, op. cit., s. 19. 
cjami ochronnymi, np. prawa do ochrony życia prywatnego"15. Jak zaznaczył Trybunał Konstytucyjny osoby pełniące funkcje publiczne ,ze względu na prawo obywateli do uzyskiwania informacji o działalności organów władzy publicznej, muszą liczyć się z obowiązkiem ujawnienia przynajmniej niektórych aspektów swojego życia prywatnego"16.

Kwestie szczegółowe precyzuje ustawa z dnia 6 września 2001 r. o dostępie do informacji publicznej ${ }^{17}$. Zgodnie $\mathrm{z}$ art. 1 tego aktu normatywnego, każda informacja o sprawach publicznych stanowi informacje publiczną $\mathrm{w}$ rozumieniu ustawy i podlega udostępnieniu na zasadach i w trybie określonych w niniejszej ustawie. Tak nakreślona definicja może budzić wątpliwości. Stąd warto zwrócić uwagę na dorobek doktryny i judykatury w tym zakresie ${ }^{18}$. Doktryna zauważa ${ }^{19}$, że informacja publiczna „oznaczać będzie wszystkie dane o sprawach publicznych uzyskiwane w jakiejkolwiek formie [...]"20. Natomiast w wyroku Wojewódzkiego Sądu Administracyjnego w Szczecinie z dnia 5 sierpnia 2010 r. ${ }^{21}$ wyrażono pogląd, że informacją publiczną jest każda wiadomość wytworzona przez szeroko rozumiane władze publiczne oraz osoby pełniące funkcje publiczne, a także inne podmioty, które tę władzę realizują, bądź gospodarują mieniem komunalnym lub majątkiem Skarbu Państwa, w zakresie swych kompetencji. Z kolei w wyroku WSA w Poznaniu z dnia

15 J. Sobczak, op. cit., s. 186.

16 Wyrok Trybunału Konstytucyjnego z dnia 13 lipca 2004 r., sygn. akt K 20/03, OTK -A 2004, nr 7, poz. 63. oraz J. Sobczak, op. cit., s. 186.

17 Dz. U. Nr 112, poz. 1198 z późn. zm. Dalej jako udip. Ponadto inne przepisy gwarantują dostęp do informacji publicznej. Warto tu wspomnieć o ustawie z dnia 8 marca 1990 r. o samorzqdzie gminnym (t.j. Dz. U. 2001, Nr 142, poz. 1591 z późn. zm. - art. 11b), ustawie z dnia 5 czerwca 1998 r. o samorzadzie powiatowym (t.j. Dz. U. 2001, Nr 142, poz. 1592 z późn. zm. - art. 8a), ustawie z dnia 5 czerwca 1998 r. o samorzqdzie województwa (t.j. Dz. U. 2001, Nr 142, poz. 1590 z późn. zm. - art. 15b). Podobnie rozdział 4 ustawy z dnia 27 sierpnia 2009 r. o finansach publicznych (Dz. U. Nr 157, poz. 1240 z późn. zm.).

18 Por. M. Jaskowska, Dostęp do informacji publicznej w świetle orzecznictwa Naczelnego Sadu Administracyjnego, Toruń 2002, s. 26.

19 J. Sobczak, Prawo prasowe. Komentarz, Warszawa 2008, s. 185; T. R. Aleksandrowicz, op. cit., s. 93-121; P. Sitniewski, Ustawa o dostęie do informacji publicznej. Komentarz, Wrocław 2011, s. 14-47.

20 M. Jabłoński, K. Wygoda, Dostęp do informacji i jego granice, Wrocław 2002, s. 111-112.

${ }^{21}$ Wyrok WSA w Szczecinie z dnia 5 sierpnia 2010 r., sygn. akt II SAB/Sz 7/10 opublik. LEX nr 668256. 
19 grudnia $2007 \mathrm{r}^{22}$ podkreślono, że przepisy ustawy o dostępie do informacji publicznej stanowią, że realizacja prawa do informacji publicznej w przewidzianych ustawą formach jest uzależniona od jednoczesnego, kumulatywnego spełnienia trzech przesłanek. Po pierwsze: przedmiotem żądania informacji musi być informacja publiczna w rozumieniu art. 1 ust. 1 i 2 ustawy oraz art. 3 ust. 2. Po drugie adresatem żądania udostępnienia informacji publicznej na zasadach tej ustawy zgodnie $\mathrm{z}$ art. 4 ust. 1 mają być ,władze publiczne oraz inne podmioty wykonujące zadania publiczne". Po trzecie: według art. 4 ust. 3 cytowanego aktu normatywnego, obowiązane do udostępnienia informacji publicznej są podmioty, o których mowa w ust. 1 i 2 ustawy będące w posiadaniu tychże informacji. Jak zaznaczono w przywoływanym orzeczeniu, uwzględniając wszystkie te aspekty, można zatem powiedzieć, że informacją publiczną będzie każda wiadomość wytworzona lub odnoszona do władz publicznych, a także wytworzona lub odnoszona do innych podmiotów wykonujących funkcje publiczne w zakresie wykonywania przez nie zadań władzy publicznej i gospodarowania mieniem komunalnym lub mieniem Skarbu Państwa. W wyroku WSA w Warszawie z dnia 18 czerwca 2009 r. ${ }^{23}$ podkreślono, że zakresem ustawy o dostępie do informacji publicznej objęte są również umowy cywilnoprawne, w tym umowy licencyjne, zawierane przez organy władzy publicznej oraz osoby pełniące funkcje publiczne, gdy dotyczą spraw publicznych. Stanowią one bowiem informacje wytworzone przez organ władzy publicznej. Dostęp do nich może jednak podlegać ograniczeniu w myśl art. 5 ust. 1 i 2 udip. W wyroku NSA w Warszawie $\mathrm{z}$ dnia 28 kwietnia $2011 \mathrm{r}^{24}$ rozstrzygnięto, że informacja o wysokości wydatków na wynagrodzenia osób pełniących funkcje związkowe jest informacją o majątku publicznym. Można się więc domagać jej udostępnienia na zasadach określonych w ustawie o dostępie do informacji publicznej.

Zgodnie z postanowieniami cytowanej ustawy prawo do informacji publicznej obejmuje uprawnienia do uzyskania informacji publicznej, w tym uzyskania informacji przetworzonej w takim zakresie, w jakim jest to szczególnie istotne dla interesu publicznego, wglądu do dokumentów urzędowych oraz dostępu do posiedzeń kolegialnych organów władzy publicznej pochodzących z powszechnych wyborów.

22 Wyrok WSA w Poznaniu z dnia 19 grudnia 2007 r., sygn. akt IV SA/Po 652/07.

23 Wyrok WSA w Warszawie z dnia 18 czerwca 2009 r., sygn. akt II SAB/Wa 14/09, opublik. LEX nr 563890.

24 Wyrok NSA w Warszawie z dnia 28 kwietnia 2011 r., sygn. akt I OSK 145/11. 
Prawo dostępu do informacji publicznych zagwarantowano każde$\mathrm{mu}^{25}$. Dodatkowo, zgodnie z art. 3a ustawy z dnia 26 stycznia 1984 r. Prawo prasowe $^{26} \mathrm{w}$ zakresie prawa dostępu prasy do informacji publicznej stosuje się przepisy ustawy o dostępie do informacji publicznej. Zatem w tym zakresie dziennikarz nie dysponuje jakimś wyjątkowym, ekskluzywnym uprawnieniem, tym niemniej jak każdy obywatel ma prawo do takich informacji ${ }^{27}$.

Zakres podmiotowy obowiązku udostępnienia informacji publicznej określono w art. 4 ustawy o dostępie do informacji publicznej. Zgodnie z nim taka powinność ciąży na władzach publicznych oraz innych podmiotach wykonujących zadania publiczne. Przepis przykładowo zalicza do tego grona m.in. podmioty reprezentujące państwowe osoby prawne albo osoby prawne samorządu terytorialnego oraz podmioty reprezentujące inne państwowe jednostki organizacyjne albo jednostki organizacyjne samorządu terytorialnego, jak również podmioty reprezentujące inne osoby lub jednostki organizacyjne, które wykonują zadania publiczne lub dysponują majątkiem publicznym, oraz osoby prawne, w których Skarb Państwa, jednostki samorządu terytorialnego lub samorządu gospodarczego albo zawodowego mają pozycję dominującą w rozumieniu przepisów o ochronie konkurencji i konsumentów ${ }^{28}$. W doktrynie podkreśla się, że jeżeli chodzi o zakres podmiotowy tego aktu, to osoby o których mowa $\mathrm{w}$ tym przepisie to pełniący funkcje kierownicze $\mathrm{w}$ tych jednostkach organizacyjnych ${ }^{29}$. Twierdzi się nadto, że osobami pełniącymi funkcje publiczne ,[...] są niewątpliwie wszyscy funkcjonariusze publiczni w rozumieniu art. $115 \S 13$ k.k. ${ }^{30}$, a oprócz nich także osoby

25 Patrz szerzej J. Sobczak, op. cit., s. 184-185. W myśl art. 10 ust. 1 udip informacja publiczna, która nie została udostępniona w „Biuletynie Informacji Publicznej", jest udostępniana na wniosek.

26 Dz. U. Nr 5, poz. 24 z późn. zm.

27 Zob. szerzej: J. Sobczak, op. cit., s. 213; Prawo prasowe. Komentarz, red. B. Kosmus, G. Kuczyński, Warszawa 2011, s. 55.

28 T. R. Aleksandrowicz, op. cit., s. 132 i n.; I. Kamińska, M. Rozbicka-Ostrowska, Dostęp do informacji publicznej. Orzecznictwo sqdów administracyjnych, Warszawa 2007, s. 68.

29 Zob. M. Bakiewicz, op. cit., s. 94.

30 Zgodnie $\mathrm{z}$ tym przepisem funkcjonariuszem publicznym jest: 1) Prezydent Rzeczypospolitej Polskiej, 2) poseł, senator, radny, 2a) poseł do Parlamentu Europejskiego, 3) sędzia, ławnik, prokurator, funkcjonariusz finansowego organu postępowania przygotowawczego lub organu nadrzędnego nad finansowym organem postępowania przygotowawczego, notariusz, komornik, kurator sądowy, syndyk, nadzorca sądowy i zarządca, osoba orzekająca w organach dyscyplinarnych działa- 
wypełniające funkcje organów władzy publicznej przez gospodarowanie mieniem komunalnym lub majątkiem Skarbu Państwa" ${ }^{\text {31 }}$. Natomiast powyższe uprawnienie nie obejmuje działalności tych osób w zakresie, w jakim nie wykonują zadań władzy publicznej i nie wykorzystują mienia publicznego ${ }^{32}$.

Dodać jednak należy, że przywoływana ustawa jednocześnie przewiduje pewne ograniczenia $\mathrm{w}$ tak nakreślonym obowiązku ${ }^{33}$. I tak zgodnie $\mathrm{z}$ art. 5 ust. 1 tego aktu normatywnego, prawo do informacji publicznej podlega ograniczeniu w zakresie i na zasadach określonych w przepisach o ochronie informacji niejawnych oraz o ochronie innych tajemnic ustawowo chronionych, jak również ze względu na prywatność osoby fizycznej ${ }^{34}$ lub tajemnicę przedsiębiorcy ${ }^{35}$. Ograniczenie to jednak nie dotyczy

jących na podstawie ustawy, 4) osoba będąca pracownikiem administracji rządowej, innego organu państwowego lub samorządu terytorialnego, chyba że pełni wyłącznie czynności usługowe, a także inna osoba w zakresie, w którym uprawniona jest do wydawania decyzji administracyjnych, 5) osoba będąca pracownikiem organu kontroli państwowej lub organu kontroli samorządu terytorialnego, chyba że pełni wyłącznie czynności usługowe, 6) osoba zajmująca kierownicze stanowisko w innej instytucji państwowej, 7) funkcjonariusz organu powołanego do ochrony bezpieczeństwa publicznego albo funkcjonariusz Służby Więziennej, 8) osoba pełniąca czynną służbę wojskową, 9) pracownik międzynarodowego trybunału karnego, chyba że pełni wyłącznie czynności usługowe. Trzeba też dodać, że Kodeks karny posługuje się także pojęciem „osoba pełniąca funkcję publiczną”. Zgodnie z art. 115 $\S 19$ jest to ,funkcjonariusz publiczny, członek organu samorządowego, osoba zatrudniona w jednostce organizacyjnej dysponującej środkami publicznymi, chyba że wykonuje wyłącznie czynności usługowe, a także inna osoba, której uprawnienia i obowiązki w zakresie działalności publicznej są określone lub uznane przez ustawę lub wiążącą Rzeczpospolitą Polską umowę międzynarodową". Wydaje się, że również ta kategoria osób objęta będzie obowiązkiem udzielenia informacji publicznej. Tak J. Sobczak, op. cit., s. 188.

31 J. Sobczak, op. cit., s. 187.

32 P. Winczorek, op. cit., s. 84.

33 R. Stefanicki, Ustawa o dostepie do informacji publicznej. Wybrane zagadnienia w świetle orzecznictwa sqdowego, „PiP” 2004, z. 2, s. 99; A. Bodzian, Tajemnica przedsiębiorstwa a dostęp do informacji o dziatalności przedsiębiorców, w: Prawo do informacji, red. W. Góralczyk jun., Warszawa 2006, s. 143-163.

${ }^{34}$ Trzeba tu jednak zaznaczyć, że w opinii TK nie ma obowiązku „zagwarantowania obywatelom dostępu do informacji za wszelką cenę". Por. wyrok TK z 19 czerwca 2002 r., sygn. akt K 11/02, OTK-A 2002, nr 4, poz. 43 oraz patrz szerzej na ten temat, J. Sobczak, op. cit., s. 186-187.

${ }_{35}$ P. Sitniewski, Ustawa ..., op. cit., s. 107-114; M. Zaremba, Prawo dostęu do informacji publicznej. Zagadnienia praktyczne, Warszawa 2009, s. 205-220. 
informacji o osobach pełniących funkcje publiczne, mających związek $\mathrm{z}$ pełnieniem tych funkcji, w tym o warunkach powierzenia i wykonywania funkcji oraz przypadku, gdy osoba fizyczna lub przedsiębiorca rezygnują z przysługującego im prawa. Dodatkowo przypomnieć należy, że w myśl art. 14 ust. 6 Prawa prasowego nie wolno bez zgody osoby zainteresowanej publikować informacji oraz danych dotyczących prywatnej sfery życia, chyba że wiąże się to bezpośrednio z działalnością publiczną danej osoby. Zagadnieniem budzącym w praktyce spore wątpliwości, jest status osób, które przestały pełnić funkcje publiczne, ale okres sprawowania przez nie określonych stanowisk, budzi w dalszym ciagu zainteresowanie określonej społeczności. Problem, którego dotyczy niniejsze opracowanie, wiąże się z występującym w takim przypadku konfliktem dwóch dóbr chronionych prawem. Z jednej strony chodzi o zapewnienie dostępu do informacji publicznych, a $z$ drugiej ochrona prywatności ${ }^{36}$.

W tym miejscy należy przypomnieć, że prywatność jest dobrem chronionym aktami prawa międzynarodowego, europejskiego, jak i krajowego. Przywołać tu trzeba art. 12 Powszechnej Deklaracji Praw Człowieka ${ }^{37}$, art. 17 Międzynarodowego Paktu Praw Obywatelskich i Politycznych ${ }^{38}$ oraz art. 8 Europejskiej Konwencji Praw Człowieka ${ }^{39}$, a także art. 7 Karty

36 A. Mednis, Prawo do prywatności a interes publiczny, Kraków 2006, s. 183-189. Autor podejmuje próbę zdefiniowania interesu publicznego.

37 Przepis ten stanowi, iż ,Nie wolno ingerować samowolnie w czyjekolwiek życie prywatne, rodzinne, domowe, ani w jego korespondencję, ani też uwłaczać jego honorowi lub dobremu imieniu. Każdy człowiek ma prawo do ochrony prawnej przeciwko takiej ingerencji lub uwłaczaniu".

38 Zgodnie z tym przepisem „1. Nikt nie może być narażony na samowolną lub bezprawną ingerencję w jego życie prywatne, rodzinne, dom czy korespondencję ani też na bezprawne zamachy na jego cześć i dobre imię. 2. Każdy ma prawo do ochrony prawnej przed tego rodzaju ingerencjami i zamachami.

${ }^{39}$ Konwencja o Ochronie Praw Człowieka i Podstawowych Wolności, t. I: Komentarz, red. L. Garlicki, Warszawa 2010, s. 490-500. Na gruncie art. 8 podkreśla się bardzo szeroką interpretację pojęcia życie prywatne. M. A. Nowicki, Europejska Konwencja Praw Człowieka. Wybór orzecznictwa, wyd. 2, Warszawa 1999, s. 330-331; idem, Nowy Europejski Trybunat Praw Człowieka. Wybór orzeczeń 1999-2004, Kraków 2005, s. 765-921. W myśl tego przepisu „Każdy ma prawo do poszanowania swojego życia prywatnego i rodzinnego, swojego mieszkania i swojej korespondencji. Niedopuszczalna jest ingerencja władzy publicznej w korzystanie $\mathrm{z}$ tego prawa, z wyjątkiem przypadków przewidzianych przez ustawę i koniecznych w demokratycznym społeczeństwie z uwagi na bezpieczeństwo państwowe, bezpieczeństwo publiczne lub dobrobyt gospodarczy kraju, ochronę porządku i zapobieganie 
Praw Podstawowych Unii Europejskiej ${ }^{40}$. Jest to także dobro prawne chronione normą konstytucyjną (art. $47 \mathrm{Konstytucji}^{41}$ ). Prawo do prywatności, definiowane jest jako jedno z chronionych dóbr osobistych, na które składa się wszystko to, co ze względu na uzasadnione odosobnienie się jednostki od ogółu społeczeństwa służy jej do rozwoju fizycznego i psychicznego $^{42}$. W doktrynie życie prywatne definiowane jest jako ,przymioty, wewnętrzne przeżycia osobiste (jednostkowo) człowieka i ich oceny, refleksje dotyczące wydarzeń zewnętrznych i jego wrażenia zmysłowe, a także stan zdrowia"43. Koncepcja ochrony życia prywatnego, najczęściej ujmowana jest w doktrynie jako kategoria nadrzędna, chroniąca wiele jednostkowych dóbr osobistych. Wskazuje się zatem na następujące możliwe sytuacje naruszające tak nakreślone prawo: a) ingerencja w życie prywatne, rodzinne, domowe; b) naruszenie integralności psychofizycznej jednostki; c) naruszenie wolności przekonań lub obyczajów człowieka; d) ukazanie innej osoby w niekorzystnym dla niej świetle; e) ujawnienie krępujących lub intymnych faktów odnoszących się do życia prywatnego jednostki; g) przywłaszczenie sobie cudzego nazwiska, pseudonimu, osiagnięcia; h) nieuzasadnione niepokojenie innej osoby poprzez śledzenie, inwigilowanie, narzucanie swojego towarzystwa lub też w inny sposób; i) naruszenie korespondencji oraz rozpowszechniania cudzego wizerunku bez zezwolenia osoby zainteresowanej; j) nadużywanie informacji uzyskanych prywatnie (ochrona wypowiedzi); k) ujawnienie informacji uzyskanej od zainteresowanego w warunkach poufności. $\mathrm{Z}$ punktu widzenia prezentowanej koncepcji niezwykle istotną rzeczą jest właściwe nakreślenie poszczególnych sfer życia osobistego, do których podmiot uprawniony ma prawo wyrażenia „zakazu wstępu” dla osób postronnych, w szczególności wobec dziennikarzy. Zaaprobować należy pogląd zakładający, iż wydzielić można trzy takie sfery. Po pierwsze chodzi tu o sferę intymności obejmującą taki zakres faktów dotyczących jednostki i jej przeżyć, którymi nie dzieli się nawet z najbliższymi osobami,

przestępstwom, ochronę zdrowia i moralności lub ochronę praw i wolności innych osób”. Patrz szerzej M. Zubik, op. cit., s. 258-261 oraz M. Zaremba, op. cit., s. 205.

40 Art. 7 tego dokumentu stanowi „Każdy ma prawo do poszanowania życia prywatnego i rodzinnego, domu i komunikowania się".

41 K. Tarnacka, Prawo..., op. cit., s. 276-284.

42 Patrz szerzej w kwestii idei prawa do prywatności J. Sobczak, op. cit., s. $570-576$.

43 B. Banaszak, s. 246. 
i których ujawnienie wywołuje uczucie wstydu i zakłopotania, a nawet udręki. Wymienić tu należy takie dobra jak: swoboda przeżyć zmysłowych dostępnych jedynie dla jego partnera, wolność przekonań i praktyk religijnych, pamięci po osobach najbliższych, cześć i honor, stosunki rodzinne w obrębie najbliższej rodziny ${ }^{44}$. Podkreślić należy, że sfera ta wymaga zawsze ochrony i naruszenie tej granicy przez osoby postronne, a zwłaszcza przez dziennikarzy winno być zabronione. Koncepcja ta pozostaje w pełni aktualna także wobec osób piastujących publiczne funkcje, oraz wszystkich tych których losy budzą żywe zainteresowanie opinii publicznej. Nie ma też żadnych istotnych powodów, nawet przy odwołaniu się argumentacji interesu publicznego, aby tę granicę dziennikarz przekraczał. Są to bowiem dobra składające się na życie wewnętrzne każdego człowieka, których poszanowanie jest niezbędne dla należytej higieny psychicznej. Twierdzi się w związku z tym, iż prywatna sfera życia $\mathrm{z}$ art. 14 ust. 6 Prawa prasowego nie obejmuje sfery intymności, którą należy traktować jako osobne dobro ${ }^{45}$. Po drugie wyróżnić można sferę prywatności, która obejmuje także sferę życia społecznego. Tradycyjnie przyjmuje się, iż w tym obszarze prawnie chronionym mieszczą się takie dobra osobiste jak życie rodzinne i sąsiedzkie, stosunki przyjacielskie i koleżeńskie. Wreszcie wymienić należy w tym katalogu sferę powszechnej dostępności. Granica pomiędzy tymi dwoma obszarami jest płynna i trudna do jednoznacznego wyznaczenia. Zaryzykować można jednak stwierdzenie, iż przebiega ona nie tam, gdzie życie prywatne rozgrywa się publicznie, lecz tam, gdzie zaczyna ono dotyczyć innych osób. Stanowisko takie wydaje się znajdować potwierdzenie w wyroku Sądu Najwyższego z 18.01.1984 r. $^{46}$, który wypowiedział się w sposób następujący: „Otwarty katalog dóbr osobistych (art. 23 i art. 24 k.c.) obejmuje także dobra osobiste związane ze sferą życia prywatnego, rodzinnego, ze strefą intymności. Ochrona w tym zakresie może odnosić się do wypadków ujawnienia faktów z życia osobistego i rodzinnego, nadużywania uzyska-

44 P. Sut, Czy sfera intymności jest dobrem osobistym chronionym $w$ prawie polskim?, „Palestra” 1995, nr 7-8, s. 49-57. Pogląd ten wydaje się obecnie dominujący, aczkolwiek znaleźć można także głosy krytyczne, por. J. Serda, Glosa do wyroku SN - Izba Cywilna z 6.12.1990 r., I CR 575/90, OSP 1992, nr 10, poz. 214.

45 Por. P. Sut, op. cit. Nie obala domniemania bezprawności działanie dziennikarza, wykazanie, iż fakty z cudzego życia intymnego ujawnione w reportażu prasowym, były obiektywnie prawdziwe. Tak SN w wyroku z 11.03.1986 r., sygn. akt I CR 4/86, zob. także glosę A. Kopffa, opublik. w OSPiKA 1987, poz. 86.

46 Wyrok SN z 18.01.1984 r., sygn. akt I CR 400/83, OSNCP 1994, nr 11, poz. 195. 
nych informacji, zbierania $\mathrm{w}$ drodze prywatnych wywiadów informacji i ocen ze sfery intymności, aby je opublikować lub w inny sposób rozgłaszać". Podobne stanowisko zaprezentowano w wyroku SN z 6.12.1990 r. ${ }^{47}$ : „Bezprawne jest rozpowszechnianie przez dziennikarza w środkach masowego przekazu bez zgody osoby zainteresowanej informacji i danych dotyczących sfery jej życia prywatnego wyłącznie z powołaniem się na prawo do przedstawiania i krytyki wszelkich zjawisk realizowane w warunkach swobodnego doboru tematu i opracowania materiału prasowego"48.

$\mathrm{Z}$ powyższego wynika, iż niewątpliwie mamy tu do czynienia z konfliktem dóbr chronionych prawnie. Rywalizują bowiem ze sobą z jednej strony prawo do informacji, a z drugiej prawo do prywatności. W tym miejscu przywołać należy art. 14 ust. 6 Prawa prasowego, zgodnie z którym zabronione jest bez zgody osoby zainteresowanej publikowanie informacji oraz danych dotyczących prywatnej sfery życia, chyba że wiąże się bezpośrednio z działalnością publiczną danej osoby. Pod pojęciem działalność publiczna rozumieć należy działalność osób, które odgrywają szczególne role w społeczeństwie, pełniąc funkcje w życiu politycznym, artystycznym, naukowym, sportowym itp. Ponadto należy mieć na uwadze powyżej akcentowaną przesłankę bezpośredniego związku publikowanych faktów ze sfery prywatnej z działalnością publiczną danej osoby. Pamiętać przy tym jednak należy, iż obowiązkiem dziennikarza (art. 10 ust. 1 Prawa prasowego) jest działanie zgodne $\mathrm{z}$ deontologią zawodową i zasadami współżycia społecznego, w granicach określonych przepisami prawa, przy zachowaniu szczególnej staranności i rzetelności (art. 12 ust. 1). Przy czym oznacza to zachowanie kwalifikowanej staranności i rzetelności ${ }^{49}$.

\footnotetext{
47 Por. wyrok SN z 6.12.1990 r., sygn. akt I CR 575/90, opublik OSN 1992, z. 10, poz. 214 .

48 Przegląd orzecznictwa w tym zakresie dokonuje J. Sobczak, op. cit., s. 597. Patrz także A. Kopff, Koncepcja praw do intymności i prywatności życia osobistego (zagadnienia konstrukcyjne), „Studia Cywilistyczne”, t. XX, s. 26; idem, Ochrona sfery życia prywatnego jednostki $w$ świetle doktryny $i$ orzecznictwa, ZNUJ Prace Prawnicze 1982, z. 100, s. 36; A. Szpunar, Ochrona dóbr osobistych, Warszawa 1979, s. 127-128; idem, Zadośćuczynienie pieniężne za doznana krzywdę w nowym prawie prasowym, „Nowe Prawo” 1984, nr 7-8, s. 6-7; K. W. Kubiński, Ochrona życia prywatnego człowieka, RPEiS 1993, z. 1, s. 63; B. Kordasiewicz, Jednostka wobec środków masowego przekazu, Wrocław 1991, s. 156-159; J. Kamieniecki, Odpowiedzialność prasy za naruszenie dóbr osobistych, PiP 1984, nr 11, s. 56.

49 Tak SN w wyroku z 8.10.1987 r., sygn. akt II CR 269/87, OSNCP 1989, nr 4, poz. 66 .
} 
Analizując problem konfliktu dwóch dóbr, a mianowicie prawa do informacji i prawa do ochrony prywatności, na uwagę zasługuje teza zaprezentowana w wyroku Wojewódzkiego Sądu Administracyjnego w Gorzowie Wielkopolskim z dnia 6 maja 2010 r. ${ }^{50}$ Otóż przesądzono tu, że cechą prawa do prywatności jest to, że ochroną tą objęta jest dziedzina życia osobistego (prywatnego), rodzinnego i towarzyskiego człowieka. Ochrona ta nie obejmuje działalności publicznej osoby ani też sfery działań i zachowań, które ogólnie są pojmowane jako osobiste lub prywatne, jeżeli działania te lub zachowania wiążą się ściśle z działalnością publiczną. Warto także przytoczyć pogląd zaprezentowany w wyroku Trybunału Konstytucyjnego z dnia 13 lipca 2004 r. ${ }^{51}$ Podkreślono, że osoby pełniące funkcje publiczne ,ze względu na prawo obywateli do uzyskiwania informacji o działalności organów władzy publicznej, muszą się liczyć z obowiązkiem ujawnienia przynajmniej niektórych aspektów życia prywatnego" ${ }^{\text {" }}$. W innym orzeczeniu $\mathrm{TK}^{53}$ także podkreślił, że mamy w takich przypadkach do rozważenia dwie wartości chronione prawem - „z jednej strony konstytucyjnego prawa do informacji, z drugiej prawa do prywatności - nie można bezwzględnie przyznać priorytetu temu pierwszemu". Podkreślono przy tym, że wykluczona jest nadmierna ingerencja w sferę życia prywatnego ${ }^{54}$. Tym niemniej jeszcze przed wprowadzeniem ustawy o dostępie do informacji publicznej, NSA w wyroku z dnia $6.05 .1997 \mathrm{r}^{55}$ zauważył, że wysokość wynagrodzenia członków zarządu gminy (wójta, burmistrza i ich zastępców) nie należy wyłącznie do sfery prywatności osób piastujących te stanowiska, gdyż wiąże się z ich funkcją publiczną. Na zasadzie art. 4 ust. 2 w związku art. 14 ust. 6 ustawy z dnia 26 stycznia 1984 r. - Prawo prasowe organ gminy nie może odmówić redaktorom prasowym udzielenia informacji o wysokości wynagrodzenia za pracę osób piastujących te stanowiska. Obecnie tego rodzaju uprawnieniem prasy należy objąć wysokość zarobków innych osób pełniących funkcje publiczne. Z kolei w wyroku NSA w Warszawie z dnia 29 lipca

${ }^{50}$ Wyrok WSA w Gorzowie Wielkopolskim z dnia 6 maja 2010 r. sygn. akt II SAB/Go 10/2010.

51 Wyroku Trybunału Konstytucyjnego z dnia 13 lipca 2004 r., K 20/03, OTK - A 2004, nr 7, poz. 63.

${ }_{52}$ Por. M. Bidziński, M. Chmaj, P. Szustakiewicz, Ustawa o dostepie do informacji publicznej. Komentarz, Warszawa 2010, s. 72.

53 Wyrok TK z 19 czerwca 2002 r., K 11/02, OTK - A 2002, nr 4, poz. 43.

${ }^{54}$ Zob. J. Sobczak, Prawo prasowe. Komentarz, Warszawa 2008, s. 186-187.

55 Wyrok NSA z dnia 6.05. 1997 r., sygn. akt II SA/Wr 929/96. 
2004 r. ${ }^{56}$ zaakcentowano, że „ustawa o dostępie do informacji publicznej reguluje kompleksowo dostęp do informacji publicznych i w ramach wykładni tych unormowań nie zachodzi potrzeba sięgania do przepisów Kodeksu cywilnego. Co niezwykle interesujące, zważywszy na przedmiot niniejszego opracowania, podkreślono tu, że „wcześniejsze pełnienie funkcji wiceburmistrza nie ma wpływu na aktualną ocenę pełnienia lub niepełnienia funkcji publicznej. Nie powinno jednak ulegać wątpliwości, że zatrudnienie takiej osoby w urzędzie miasta, na podstawie umowy cywilnej, samo przez się (tylko ze względu na rodzaj zawartej umowy) nie wyłącza możliwości uznania takiej osoby za osobę wykonującą funkcje publiczne lub też osobę mającą związek $\mathrm{z}$ pełnieniem funkcji publicznych. Skoro tak, to otwartą kwestią jest odpowiedź na pytanie, jakiego rodzaju czynności wykonywane są przez tę osobę. Nie może zatem być uznane za wystarczające powołanie się przez sąd jedynie na rodzaj umowy oraz sam fakt sprawowania nadzoru nad inwestycjami",57.

W doktrynie odnaleźć można pogląd, że ,[...] osobę, która w przeszłości pełniła funkcje publiczne i działała w sferze publicznej można potraktować jako osobę publiczną w momencie, w którym tych funkcji już nie wykonuje jedynie wyjątkowo. Jest to usprawiedliwione jedynie w przypadku publikacji o historycznym znaczeniu. Ponadto osoba ta powinna odgrywać szczególną rolę w wydarzeniach historycznych, które mają być treścią publikacji prasowych"58. Inni autorzy podkreślają, że „ochrona prywatności i tajemnica przedsiębiorstwa nie mogą jednak stanowić podstawy odmowy wówczas, gdy informacje dotyczą osób pełniących funkcje publiczne, w zakresie, w jakim mają związek z pełnieniem tych funkcji" ${ }^{59}$. Zatem w przypadku złożenia wniosku o dostęp do informacji publicznej dotyczącego okresu, kiedy dana osoba pełniła funkcję publiczną, wydaje się, że taką informacje należy udzielić. Żądanie takie dotyczy nie obecnej sytuacji prawnej i faktycznej takiej osoby, która dziś już nie pełni tej funkcji, lecz okresu poprzedniego, który wywiera skutek na dziś i w bezpośrednim związku z pełnieniem takiej funkcji. Zasady logiki każą przyjąć, iż gdyby wystąpiono o tę samą informację wcześniej, w okresie kiedy dana osoba sprawowała swoją funkcję w pod-

56 Wyrok NSA w Warszawie z dnia 29 lipca 2004 r., sygn. akt OSK 693/04.

57 Ibidem.

58 Tak J. D. Sieńczyło-Chlabicz, Naruszenie prywatności osób publicznych przez prase. Analiza cywilnoprawna, Kraków 2006, s. 233.

59 B. Kosmus, G. Kuczyński, op. cit., s. 65. 
miocie, który objęty jest zakresem regulacji ustawy o dostępie do informacji publicznej (np. w spółce będącej w 100\% własnością komunalną), to taką informację ten podmiot byłby zobowiązany udostępnić. A tylko $\mathrm{z}$ tego powodu, że o tę samą informację wystąpiono po ustąpieniu ze stanowiska, to próbę odmowy dostępu do informacji publicznej, należy ocenić jako działanie bezprawne. Gdyby przyjąć odmienne stanowisko, zabieg polegający na ustąpieniu ze stanowiska, byłby doskonałym fortelem, pozwalającym uniknąc ujawnienia informacji budzących społeczne zainteresowanie. Wydaje się, że tendencja do zapewniania coraz większej przejrzystości życia publicznego jest dziś powszechnie akceptowana, a powyższa konkluzja w ten trend naturalnie się wpisuje ${ }^{60}$.

\section{Access to public information as opposed to the protection of the privacy of those who cease to hold public office}

\section{Summary}

The practice of granting access to public information raises considerable controversies over the status of the individuals who cease to hold public office but where the period of their activity continues to be of interest to the public. This paper discusses the issue of the conflict of two values protected by the law. On one hand we are dealing with granting access to public information, on the other with the protection of privacy.

60 Aczkolwiek ostatnie próby zmiany obowiązującego stanu prawnego, które wywołują spore kontrowersje, mogą sugerować odmienny kierunek. 